\title{
Phosphate binders in patients with chronic kidney disease
}

\section{SUMMARY}

Hyperphosphataemia in patients with chronic kidney disease, particularly those on dialysis, can be ameliorated by oral phosphate binders in conjunction with dietary phosphate restriction.

Although phosphate binders reduce serum phosphate in these patients, it remains uncertain whether they improve clinical outcomes.

Calcium-based binders are frequently used, but their popularity is waning due to emerging evidence of accelerated vascular calcification.

The use of aluminium-based binders has been limited by a perceived risk of aluminium accumulation.

The non-calcium-based phosphate binders - sevelamer hydrochloride, lanthanum carbonate and sucroferric oxyhydroxide - have become available and subsidised by the Pharmaceutical Benefits Scheme for patients on dialysis.

The pill burden and adverse effects (particularly gastrointestinal intolerance) associated with phosphate binders often contribute to poor medication adherence.

\section{Introduction}

Hyperphosphataemia is an independent predictor of cardiovascular disease and mortality in patients with advanced chronic kidney disease (stage 4 and 5) and is due to impaired phosphate excretion by the kidney. ${ }^{1-3}$ It is typically managed with oral phosphate binders in conjunction with dietary phosphate restriction. These drugs aim to lower serum phosphate by reducing intestinal absorption of dietary phosphate. Hyperphosphataemia is normally asymptomatic. However, phosphate binders may provide symptomatic relief from pruritus and red irritated eyes, which are more commonly reported in patients with serum phosphate elevations greater than $1.8 \mathrm{mmol} / \mathrm{L} .4,5$ Phosphate binders are a commonly prescribed class of drug for patients on dialysis. In Australia, the annual expense for phosphate binders has increased significantly since sevelamer hydrochloride and lanthanum carbonate were included on the Pharmaceutical Benefits Scheme (PBS), with the mean pill cost increasing from $\$ 12.85$ to $\$ 59.85$ per patient per week. ${ }^{6}$ There is a lack of trial evidence for both benefit in patients and cost-effectiveness of phosphate lowering. ${ }^{7}$ Phosphate binders may also account for up to $50 \%$ of the daily pill burden in patients with chronic kidney disease. ${ }^{8}$ Together with frequent adverse drug effects (particularly gastrointestinal intolerance), this contributes to poor medication adherence. ${ }^{9}$

\section{Phosphate binders}

There are three main types of phosphate binders available - calcium-containing binders and aluminium-containing binders, which have been around for many years and are cheap, and the new non-calcium-based binders (sevelamer, lanthanum and sucroferric oxyhydroxide) which are considerably more expensive (see Table) . $^{-3}$

Calcium carbonate is the most common form of phosphate binder prescribed, particularly in nondialysis chronic kidney disease. It is typically given to patients with advanced chronic kidney disease, including those receiving dialysis. As with all phosphate binders, calcium-based binders are most effective when taken with meals (which also limits calcium absorption). ${ }^{10}$ They should be prescribed in conjunction with moderate dietary phosphate restriction, ideally supervised by an accredited practising dietitian. Phosphate-rich foods with a high phosphate to protein ratio (processed foods, fast foods and cola drinks) are best avoided, while foods with a high biologic value (e.g. meats and eggs) should be retained to maintain nutritional status. ${ }^{11,12}$ Aluminium-based binders are a second-line drug in non-dialysis chronic kidney disease. The other newer non-calcium-based binders - sevelamer, lanthanum and sucroferric oxyhydroxide - are only available under the PBS for dialysis patients.

\section{Samuel Chan}

Nephrology advanced trainee

Associate lecturer ${ }^{2}$

\section{Kenneth Au}

Resident medical officer

\section{Ross S Francis}

Consultant nephrologist

Senior lecturer ${ }^{2}$

\section{David W Mudge}

Consultant nephrologist

Associate professor ${ }^{2}$

\section{David W Johnson}

Consultant nephrologist and Director

Professor ${ }^{2}$

\section{Peter I Pillans}

Consultant and Director ${ }^{3}$

Associate professor ${ }^{2}$

'Department of Nephrology Princess Alexandra Hospital

2 School of Medicine University of Queensland

${ }^{3}$ Department of Clinical Pharmacology

Princess Alexandra Hospital Brisbane

\section{Keywords}

chronic kidney disease drug compliance, drug costs, hyperphosphataemia, phosphate binders, pill burden

Aust Prescr 2017:40:9-14 http://dx.doi.org/10.18773/ austprescr.2017.002 


\section{Table Characteristics of oral phosphate binders available in Australia}

\begin{tabular}{|c|c|c|c|c|c|c|c|}
\hline $\begin{array}{l}\text { Phosphate } \\
\text { binders }\end{array}$ & $\begin{array}{l}\text { Mechanism of } \\
\text { action }\end{array}$ & $\begin{array}{l}\text { Form, } \\
\text { strength }\end{array}$ & Initial dose & $\begin{array}{l}\text { Maximum } \\
\text { recommended } \\
\text { dose }\end{array}$ & Cost per tablet & Advantages & Disadvantages \\
\hline $\begin{array}{l}\text { Aluminium } \\
\text { hydroxide }\end{array}$ & $\begin{array}{l}\text { Forms insoluble } \\
\text { phosphate } \\
\text { complexes in } \\
\text { the gut }\end{array}$ & $\begin{array}{l}600 \mathrm{mg} \\
\text { tablets }\end{array}$ & $\begin{array}{l}1 \text { tablet } \\
3 \text { times a day } \\
\text { with meals }\end{array}$ & $\begin{array}{l}2 \text { tablets } \\
3 \text { times a day } \\
\text { with meals }\end{array}$ & 20 cents & $\begin{array}{l}\text { Inexpensive, } \\
\text { calcium-free, } \\
\text { binds phosphate } \\
\text { at wide range } \\
\text { of pH }\end{array}$ & $\begin{array}{l}\text { No safe dose established, } \\
\text { significant adverse effects } \\
\text { (e.g. potential central nervous } \\
\text { system toxicity, microcytic } \\
\text { anaemia, osteomalacia, } \\
\text { gastrointestinal upset), requires } \\
\text { regular monitoring of serum } \\
\text { aluminium }\end{array}$ \\
\hline $\begin{array}{l}\text { Calcium } \\
\text { carbonate }\end{array}$ & $\begin{array}{l}\text { Forms insoluble } \\
\text { phosphate } \\
\text { complexes in } \\
\text { the gut }\end{array}$ & $\begin{array}{l}\text { Chewable } \\
\text { tablets, } \\
500 \mathrm{mg} \text {, } \\
600 \mathrm{mg} \\
\text { elemental } \\
\text { calcium }\end{array}$ & $\begin{array}{l}1 \text { tablet } \\
3 \text { times a day } \\
\text { with meals }\end{array}$ & $\begin{array}{l}1 \text { tablet } \\
3 \text { times a day } \\
\text { with meals }\end{array}$ & 17 cents & $\begin{array}{l}\text { Moderately } \\
\text { effective, } \\
\text { relatively } \\
\text { inexpensive }\end{array}$ & $\begin{array}{l}\text { Hypercalcaemia, large doses } \\
\text { required to be effective, } \\
\text { possible vascular calcification, } \\
\text { unpalatable }\end{array}$ \\
\hline $\begin{array}{l}\text { Sevelamer } \\
\text { hydrochloride }\end{array}$ & $\begin{array}{l}\text { An anion } \\
\text { exchange resin }\end{array}$ & $\begin{array}{l}800 \mathrm{mg} \\
\text { tablets }\end{array}$ & $\begin{array}{l}\text { 1-3 tablets } \\
\text { a day with } \\
\text { meals }\end{array}$ & $0.3 \mathrm{~g} / \mathrm{kg} /$ day & $\$ 1.72$ & $\begin{array}{l}\text { Calcium-free, } \\
\text { lipid-lowering } \\
\text { effect }\end{array}$ & $\begin{array}{l}\text { Expensive, high pill burden, } \\
\text { gastrointestinal adverse effects } \\
\text { (bloating) }\end{array}$ \\
\hline $\begin{array}{l}\text { Lanthanum } \\
\text { carbonate }\end{array}$ & $\begin{array}{l}\text { Forms insoluble } \\
\text { phosphate } \\
\text { complexes in } \\
\text { the gut }\end{array}$ & $\begin{array}{l}500 \mathrm{mg}, \\
750 \mathrm{mg}, \\
1000 \mathrm{mg} \\
\text { chewable } \\
\text { tablets }\end{array}$ & $\begin{array}{l}500-750 \text { mg } \\
3 \text { times a day } \\
\text { with meals }\end{array}$ & $\begin{array}{l}1000 \mathrm{mg} \\
3 \text { times a day } \\
\text { with meals }\end{array}$ & $\begin{array}{l}500 \mathrm{mg} \$ 2.91 \\
750 \mathrm{mg} \$ 4.39 \\
1000 \mathrm{mg} \$ 4.94\end{array}$ & $\begin{array}{l}\text { Low pill burden, } \\
\text { high efficacy, } \\
\text { works in wide } \\
\text { range of } \mathrm{pH} \text {, } \\
\text { no negative } \\
\text { changes on } \\
\text { bone histology }\end{array}$ & $\begin{array}{l}\text { Expensive, gastrointestinal } \\
\text { adverse effects, uncertain } \\
\text { long-term effects }\end{array}$ \\
\hline $\begin{array}{l}\text { Sucroferric } \\
\text { oxyhydroxide }\end{array}$ & $\begin{array}{l}\text { A ligand } \\
\text { exchange } \\
\text { iron-based } \\
\text { compound }\end{array}$ & $\begin{array}{l}500 \mathrm{mg} \\
\text { chewable } \\
\text { tablets }\end{array}$ & $\begin{array}{l}1 \text { tablet } \\
3 \text { times a day } \\
\text { with meals }\end{array}$ & 6 tablets per day & $\$ 4.19$ & $\begin{array}{l}\text { Low pill burden, } \\
\text { works in wide } \\
\text { range of } \\
\mathrm{pH} \text {, minimal } \\
\text { systemic } \\
\text { absorption }\end{array}$ & $\begin{array}{l}\text { Expensive, gastrointestinal } \\
\text { adverse effects (stool } \\
\text { discoloration) }\end{array}$ \\
\hline
\end{tabular}

For all binders except lanthanum and sucroferric oxyhydroxide, the starting dose is typically 1-2 tablets three times daily with each meal, depending on potency. Between-meal snacks are often covered with half a tablet. For calcium-based binders and sevelamer, the dose can be increased to a maximum of six or more tablets daily. Other medicines should be given separately as phosphate binders can interfere with the absorption of drugs such as oral iron ${ }^{13}$ and ciprofloxacin. ${ }^{14}$

\section{Calcium-containing phosphate binders}

Calcium binders have historically been an appealing first choice, because they also address the hypocalcaemia that is often seen with hyperphosphataemia in patients with chronic kidney disease. However, hypercalcaemia and accelerated vascular calcification are the main concerns with calcium-containing phosphate binders, particularly when they are combined with vitamin D therapy. ${ }^{5,15-18}$
The Kidney Disease Outcomes Quality Initiative Guidelines suggest that doses should not exceed $1500 \mathrm{mg} /$ day of elemental calcium, ${ }^{19}$ based on evidence that this produces a positive calcium balance (excess body stores of calcium leading to soft-tissue and vessel calcification) in chronic kidney disease. ${ }^{20}$ However, there is little evidence of patient outcomes to support this recommendation. Another common adverse effect of these drugs is gastrointestinal upset, particularly constipation. The other main advantage of calcium-based binders is that they are inexpensive.

\section{Aluminium-containing phosphate binders}

Aluminium hydroxide has an excellent phosphatebinding capacity and has been used for over three decades. A number of (principally US-based) guidelines advise against long-term use of aluminiumbased binders because of concerns about aluminium intoxication (dementia, osteomalacia, anaemia). ${ }^{21}$ This is despite little evidence of toxicity with these 
drugs in an era of ultrapure dialysis water quality. ${ }^{22}$ Some European countries as well as Australia still use aluminium for this purpose but regular testing of dialysis water is mandatory if aluminium is to be used orally. Also, oral citrate must be avoided in patients taking aluminium binders as this has been shown to lead to enhanced absorption and cases of neurological toxicity. ${ }^{23}$ There are a limited number of small randomised trials examining the efficacy and safety of aluminium as a binder. However, they were inadequately powered for examining patient-level outcomes. ${ }^{24-29}$

\section{Sevelamer hydrochloride}

Sevelamer is the most commonly prescribed noncalcium-based phosphate binder, but has a lower phosphate-binding capacity than other phosphate binders. Its off-target effects include lowering serum low-density lipoprotein cholesterol and increasing the concentrations of fetuin-A (calcification inhibitor). ${ }^{30}$ However, these effects have not been shown to improve cardiovascular outcomes for dialysis patients in prospective trials.

The primary disadvantages of this drug are its high price and high pill burden. It may also reduce the bioavailability of fat-soluble vitamins. Its main adverse effects are gastrointestinal intolerance and metabolic acidosis. ${ }^{31}$

\section{Lanthanum carbonate}

Lanthanum is a trivalent metal phosphate binder which has a similar affinity for phosphate as aluminium-based drugs. ${ }^{32}$ It is roughly twice as potent as calcium and sevelamer. Lanthanum powder is more effective than chewable tablets ${ }^{33,34}$ and reduces the pill burden. ${ }^{35}$ It is also the only oral phosphate binder to come in three different tablet strengths, meaning the maximum number of tablets per day is always three. Despite poor intestinal absorption, lanthanum may deposit in tissues, particularly liver and bone. ${ }^{36}$ However, in studies with extended follow-up there is no evidence of clinical hepatotoxicity ${ }^{37}$ and bone toxicity. ${ }^{38,39}$ Like other phosphate binders, lanthanum may cause gastrointestinal intolerance, particularly nausea. Similarly to sevelamer, this drug is expensive.

\section{Sucroferric oxyhydroxide}

Sucroferric oxyhydroxide is now registered in Australia as an iron-based phosphate binder for patients with chronic kidney disease on dialysis. Phosphate binding occurs across a wide range of stomach $\mathrm{pH}$, with a peak at $\mathrm{pH} 2.5 .{ }^{40}$ Common adverse effects include diarrhoea and change in stool colour. There was no evidence of iron accumulation in a phase III extension study. ${ }^{41,42}$ The binder has a similar pill burden to lanthanum carbonate, as it is given as one pill with each meal and is easily chewable, which may improve patient adherence. ${ }^{43}$ The cost of sucroferric oxyhydroxide is similar to lanthanum and sevelamer.

\section{Other phosphate binders}

A number of other drugs have been used as phosphate binders, including sevelamer carbonate, ${ }^{44}$ calcium acetate, ${ }^{45}$ magnesium carbonate, ${ }^{46}$ ferric citrate, ${ }^{47}$ colestilan, ${ }^{48}$ bixalomer ${ }^{49}$ and nicotinic acid ${ }^{50}$ but are not registered in Australia for this purpose.

\section{How effective are phosphate binders in chronic kidney disease?}

Despite evidence that phosphate binders reduce serum phosphate, a recent Cochrane review involving 7631 participants from 60 studies found no convincing evidence for improvements in all-cause or cardiovascular mortality, vascular calcification or fracture risk..$^{51}$

Calcium-based binders were associated with significantly lower serum phosphate (mean difference $0.07 \mathrm{mmol} / \mathrm{L}$ ) when compared with sevelamer. However, sevelamer was associated with a lower risk of hypercalcaemia (risk ratio $0.45,95 \% \mathrm{Cl}^{*} 0.35-0.59$ ) and a higher risk of adverse gastrointestinal events (risk ratio 1.58, 95\% $\mathrm{Cl} 1.11-1.25$ ). There was no difference in all-cause mortality between calciumbased binders and sevelamer. ${ }^{51}$

A meta-analysis of 11 randomised, controlled trials found that patients treated with non-calcium-based binders had a $22 \%$ decreased risk of all-cause mortality (risk ratio $0.78,95 \% \mathrm{Cl} 0.61-0.98$ ) compared with patients treated with calcium-based binders. ${ }^{52}$ However, the results were limited by moderate trial heterogeneity. No significant benefit of non-calciumbased binders was evident in large trials, or after correcting for publication bias or removing a trial with a high risk of bias. ${ }^{53-55}$

A recent meta-analysis of phosphate binders reported that no phosphate binder reduced mortality compared to placebo in adults with chronic kidney disease. ${ }^{56}$ More importantly, sevelamer resulted in lower mortality than calcium-based drugs, while the comparative effects of lanthanum, iron-based drugs and colestilan were less certain. ${ }^{56}$

Phosphate binders therefore effectively reduce serum phosphate in patients with chronic kidney disease, but it is uncertain whether they improve clinical outcomes. There may be a mortality difference between calciumbased and non-calcium-based binders, but it is not

\footnotetext{
* confidence interval
} 
clear if this reflects a harmful effect of calcium-based binders, a beneficial effect of non-calcium-based binders or both.

This raises the economic argument of costeffectiveness. The older binders such as calcium carbonate and aluminium hydroxide are cheaper (a few cents per tablet) than the newer binders sevelamer, lanthanum and sucroferric oxyhydroxide (see Table). This makes use of the newer binders potentially harder to justify..$^{54,55}$

\section{Guidelines}

Based on poor quality and conflicting evidence, guidelines make weak suggestions that oral phosphate binders should be used for hyperphosphataemia-complicating chronic kidney disease to maintain serum phosphate in the normal

\section{Fig. Prescribing phosphate binders for hyperphosphataemia in patients with chronic kidney disease}

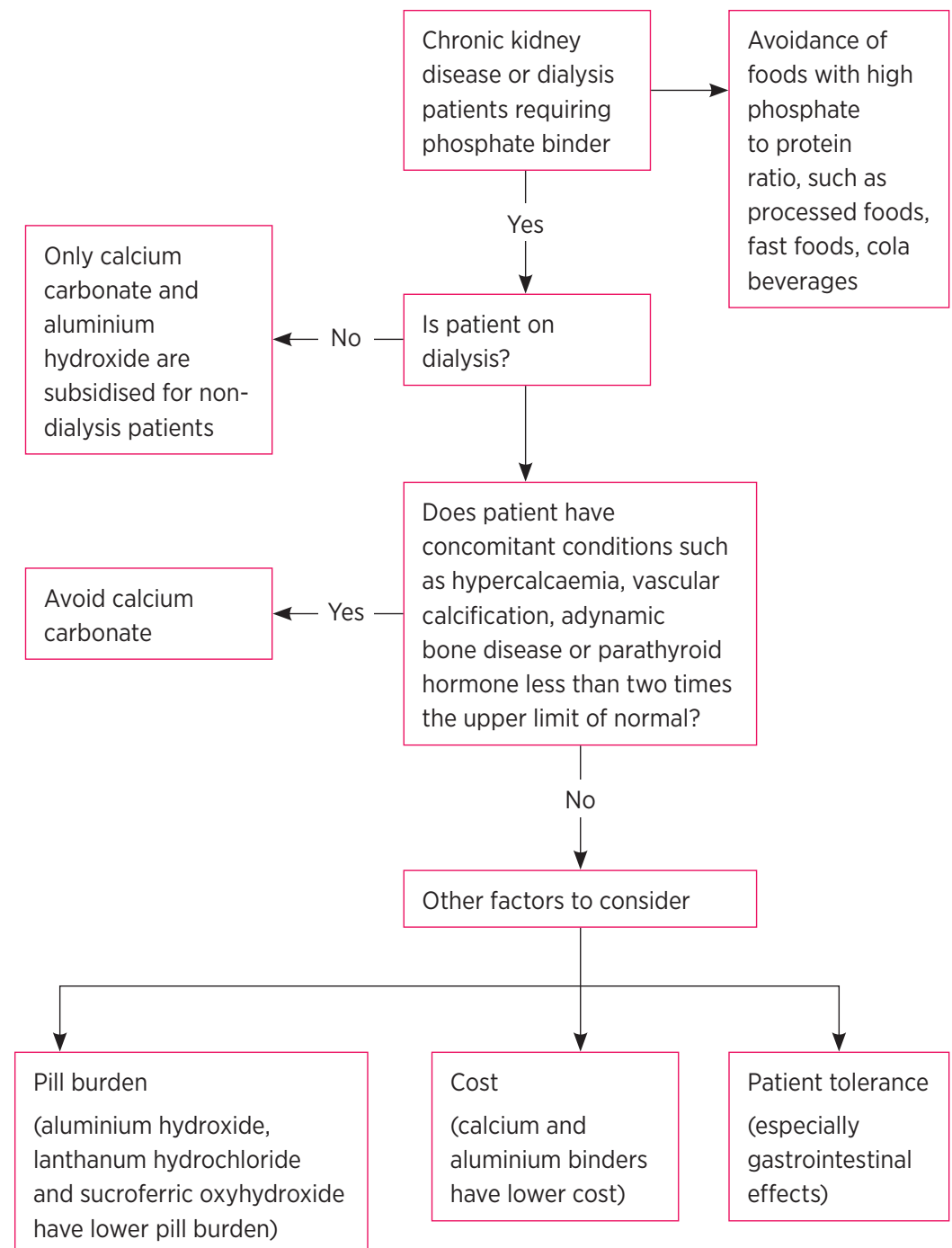

range..$^{22}$ They also suggest that calcium-based binders should be dose restricted (or avoided) in the following circumstances:

- the presence of hypercalcaemia

- arterial calcification

- adynamic bone disease (a low bone turnover condition) or serum parathyroid hormone concentrations that are less than two times the upper limit of the laboratory reference range. ${ }^{\dagger}$

Long-term use of aluminium-based binders is advised against because of the potential risk of toxicity.

The Kidney Health Australia guidelines - Caring for Australasians with Renal Impairment (KHA-CARI) recommend that phosphate binders are effective in reducing serum phosphate in advanced kidney disease. ${ }^{57}$ Calcium salt-based binders are recommended as first-line drugs but their use should be minimised when serum calcium is above the target range $(2.4 \mathrm{mmol} / \mathrm{L})$ or serum parathyroid hormone is below the upper limit of the reference range. ${ }^{57}$

\section{Conclusion}

Oral phosphate binders are widely used for hyperphosphataemia in patients with advanced chronic kidney disease, although it remains uncertain whether they improve patient outcomes such as renal bone disease, cardiovascular events and mortality.

Calcium carbonate is the most commonly used phosphate binder, but clinicians are increasingly prescribing the more expensive, non-calcium-based phosphate binders, particularly sevelamer. ${ }^{6}$ This is primarily because emerging evidence suggests calcium-based binders may accelerate vascular calcification and cardiovascular mortality.

If a phosphate binder is prescribed, choice will be influenced by whether or not the patient is on dialysis because non-calcium binders (lanthanum carbonate, sevelamer hydrochloride and sucroferric oxyhydroxide) are not available on the PBS for non-dialysis patients. Cost, concomitant conditions, pill burden and patient tolerance should also be considered (see Fig.). Prescription should be accompanied by dietary advice, patient education and regular assessment of adherence. $<$

\section{Conflict of interest: none declared}

t The desired parathyroid hormone concentration in chronic kidney disease is more than two times the upper limit of normal. If it is less than this, the patient may be at risk of adynamic bone disease. 
1. Covic A, Kothawala P, Bernal M, Robbins S, Chalian A Goldsmith D. Systematic review of the evidence underlying the association between mineral metabolism disturbances and risk of all-cause mortality, cardiovascular mortality and cardiovascular events in chronic kidney disease. Nephrol Dial Transplant 2009;24:1506-23. http://dx.doi.org/ 10.1093/ndt/gfn613

2. Isakova T, Gutiérrez OM, Chang Y, Shah A, Tamez H, Smith K, et al. Phosphorus binders and survival on hemodialysis. J Am Soc Nephrol 2009;20:388-96. http://dx.doi.org/ 10.1681/ASN.2008060609

3. Palmer SC, Hayen A, Macaskill P, Pellegrini F, Craig JC, Elder GJ, et al. Serum levels of phosphorus, parathyroid hormone, and calcium and risks of death and cardiovascular disease in individuals with chronic kidney disease: a systematic review and meta-analysis. JAMA 2011;305:1119-27. http://dx.doi.org/10.1001/jama.2011.308

4. Wikström B. Itchy skin--a clinical problem for haemodialysis patients. Nephrol Dial Transplant 2007;22 Suppl 5:v3-7. http://dx.doi.org/10.1093/ndt/gfm292

5. Mofty M, Youssef RM, Tawfic SO, Abdel-Halim MR, Abozeid H, Shaker OG, et al. Skin and serum levels of calcium, phosphorus and vitamin D3 in uremic pruritus patients before and after broad band ultraviolet B (UVB) phototherapy. Egyptian Dermatology Online Journal 2006;2:1.

6. Gray NA, Krishnasamy R, Vardesh DL, Hollett PR, Anstey CM. Impact of non-traditional phosphate binders and cinacalcet on haemodialysis patient biochemistry, pill burden and cost. Nephrology (Carlton) 2011;16:688-96. http://dx.doi.org/ 10.1111/j.1440-1797.2011.01482.x

7. Chue CD, Townend JN, Moody WE, Zehnder D, Wall NA, Harper L, et al. Cardiovascular effects of sevelamer in stage 3 CKD. J Am Soc Nephrol 2013;24:842-52. http://dx.doi.org/10.1681/ASN.2012070719

8. Chiu YW, Teitelbaum I, Misra M, de Leon EM, Adzize T, Mehrotra R. Pill burden, adherence, hyperphosphatemia, and quality of life in maintenance dialysis patients. Clin J Am Soc Nephrol 2009;4:1089-96. http://dx.doi.org/ 10.2215/CJN.00290109

9. Fissell RB, Karaboyas A, Bieber BA, Sen A, Li Y, Lopes AA, et al. Phosphate binder pill burden, patient-reported nonadherence, and mineral bone disorder markers: findings from the DOPPS. Hemodial Int 2016:20:38-49. http://dx.doi.org/10.1111/hdi.12315

10. Schiller LR, Santa Ana CA, Sheikh MS, Emmett M, Fordtran JS Effect of the time of administration of calcium acetate on phosphorus binding. N Engl J Med 1989;320:1110-3. http://dx.doi.org/10.1056/NEJM198904273201703

11. Sullivan C, Sayre SS, Leon JB, Machekano R, Love TE, Porter D, et al. Effect of food additives on hyperphosphatemia among patients with end-stage renal disease: a randomized controlled trial. JAMA 2009;301:629-35. http://dx.doi.org/ 10.1001/jama.2009.96

12. Berkoben M, Quarles LD. Treatment of hyperphosphataemia in chronic kidney disease. UpToDate 4 May 2016. www.uptodate.com [cited 2017 Jan 9]

13. Pruchnicki MC, Coyle JD, Hoshaw-Woodard S, Bay WH. Effect of phosphate binders on supplemental iron absorption in healthy subjects. J Clin Pharmacol 2002;42:1171-6. http://dx.doi.org/10.1177/009127002401382669

14. How PP, Fischer JH, Arruda JA, Lau AH. Effects of lanthanum carbonate on the absorption and oral bioavailability of ciprofloxacin. Clin J Am Soc Nephrol 2007;2:1235-40. http://dx.doi.org/10.2215/CJN.01580407

15. Levin A, Bakris GL, Molitch M, Smulders M, Tian J, Williams $L A$, et al. Prevalence of abnormal serum vitamin $\mathrm{D}, \mathrm{PTH}$, calcium, and phosphorus in patients with chronic kidney disease: results of the study to evaluate early kidney disease. Kidney Int 2007;71:31-8. http://dx.doi.org/10.1038/ sj.ki.5002009

16. Shantouf R, Ahmadi N, Flores F, Tiano J, Gopal A, Kalantar-Zadeh K, et al. Impact of phosphate binder type on coronary artery calcification in hemodialysis patients. Clin Nephrol 2010;74:12-8. http://dx.doi.org/10.5414/ CNP74012
17. Chertow GM, Burke SK, Raggi P; Treat to Goal Working Group. Sevelamer attenuates the progression of coronary and aortic calcification in hemodialysis patients. Kidney Int 2002;62:245-52. http://dx.doi.org/10.1046 /j.1523-1755.2002.00434.x

18. Toussaint ND, Lau KK, Polkinghorne KR, Kerr PG. Attenuation of aortic calcification with lanthanum carbonate versus calcium-based phosphate binders in haemodialysis: a pilot randomized controlled trial. Nephrology (Carlton) 2011;16:290-8. http://dx.doi.org/ 10.1111/j.1440-1797.2010.01412.x

19. London G, Coyne D, Hruska K, Malluche HH, Martin KJ. The new kidney disease: improving global outcomes (KDIGO) guidelines - expert clinical focus on bone and vascular calcification. Clin Nephrol 2010;74:423-32.

20. Hill KM, Martin BR, Wastney ME, McCabe GP, Moe SM, Weaver CM, et al. Oral calcium carbonate affects calcium but not phosphorus balance in stage 3-4 chronic kidney disease. Kidney Int 2013;83:959-66. http://dx.doi.org/10.1038/ ki.2012.403

21. Kidney Disease: Improving Global Outcomes (KDIGO) CKDMBD Work Group. KDIGO clinical practice guideline for the diagnosis, evaluation, prevention, and treatment of chronic kidney disease-mineral and bone disorder (CKD-MBD). Kidney Int 2009;76:S1-130.

22. Mudge DW, Johnson DW, Hawley CM, Campbell SB Isbel NM, van Eps CL, et al. Do aluminium-based phosphate binders continue to have a role in contemporary nephrology practice? BMC Nephrol 2011;12:20. http://dx.doi.org/10.1186/ 1471-2369-12-20

23. Alfrey AC. Aluminum toxicity in patients with chronic renal failure. Ther Drug Monit 1993;15:593-7. http://dx.doi.org/ 10.1097/00007691-199312000-00025

24. Katopodis KP, Andrikos EK, Gouva CD, Bairaktari ET, Nikolopoulos PM, Takouli LK, et al. Sevelamer hydrochloride versus aluminum hydroxide: effect on serum phosphorus and lipids in CAPD patients. Perit Dial Int 2006;26:320-7.

25. Janssen MJ, van der Kuy A, ter Wee PM, van Boven WP. Aluminum hydroxide, calcium carbonate and calcium acetate in chronic intermittent hemodialysis patients. Clin Nephrol 1996;45:111-9.

26. Jespersen B, Jensen JD, Nielsen HK, Lauridsen IN, Andersen MJ, Poulsen JH, et al. Comparison of calcium carbonate and aluminium hydroxide as phosphate binders on biochemical bone markers, PTH(1-84), and bone mineral content in dialysis patients. Nephrol Dial Transplant 1991;6:98-104. http://dx.doi.org/10.1093/ndt/6.2.98

27. Salusky IB, Foley J, Nelson P, Goodman WG. Aluminum accumulation during treatment with aluminum hydroxide and dialysis in children and young adults with chronic renal disease. N Engl J Med 1991;324:527-31. http://dx.doi.org/ 10.1056/NEJM199102213240804

28. Roxe DM, Mistovich M, Barch DH. Phosphate-binding effects of sucralfate in patients with chronic renal failure. Am J Kidney Dis 1989;13:194-9. http://dx.doi.org/10.1016/ S0272-6386(89)80052-6

29. Mak RH, Turner C, Thompson T, Powell H, Haycock GB, Chantler C. Suppression of secondary hyperparathyroidism in children with chronic renal failure by high dose phosphate binders: calcium carbonate versus aluminium hydroxide. Br Med J (Clin Res Ed) 1985;291:623-7. http://dx.doi.org/ 10.1136/bmj.291.6496.623

30. Zhang Q, Li M, Lu Y, Li H, Gu Y, Hao C, et al. Meta-analysis comparing sevelamer and calcium-based phosphate binders on cardiovascular calcification in hemodialysis patients. Nephron Clin Pract 2010;115:c259-67. http://dx.doi.org/ $10.1159 / 000313484$

31. Fishbane S, Delmez J, Suki WN, Hariachar SK, Heaton J, Chasan-Taber S, et al. A randomized, parallel, open-label study to compare once-daily sevelamer carbonate powder dosing with thrice-daily sevelamer hydrochloride tablet dosing in CKD patients on hemodialysis. Am J Kidney Dis 2010;55:307-15. http://dx.doi.org/10.1053/j.ajkd.2009.10.051

32. Finn WF; SPD 405-307 Lanthanum Study Group. Lanthanum carbonate versus standard therapy for the treatment of hyperphosphatemia: safety and efficacy in chronic maintenance hemodialysis patients. Clin Nephro 2006;65:191-202. http://dx.doi.org/10.5414/CNP65191 
33. Sakurada T, Oishi D, Shibagaki Y, Yasuda T, Kimura K. Efficacy of oral powder compared with chewable tablets for lanthanum carbonate administration in hemodialysis patients. Hemodial Int 2013;17 Suppl 1:S2-6. http://dx.doi.org/ 10.1111/hdi.12081

34. Pierce D, Hossack S, Robinson A, Zhang P, Martin P. Assessment of pharmacodynamic equivalence and tolerability of lanthanum carbonate oral powder and tablet formulations: a single-center, randomized, openlabel, 2-period crossover study in healthy subjects. Clin Ther 2012;34:1290-300.e2. http://dx.doi.org/10.1016/ j.clinthera.2012.05.003

35. Hutchison AJ, Laville M; SPD405-313 Lanthanum Study Group. Switching to lanthanum carbonate monotherapy provides effective phosphate control with a low tablet burden. Nephrol Dial Transplant 2008;23:3677-84. http://dx.doi.org/10.1093/ndt/gfn310

36. Zhang C, Wen J, Li Z, Fan J. Efficacy and safety of lanthanum carbonate on chronic kidney disease-mineral and bone disorder in dialysis patients: a systematic review. BMC Nephrol 2013;14:226. http://dx.doi.org/10.1186/ 1471-2369-14-226

37. Hutchison AJ, Barnett ME, Krause R, Kwan JTC, Siami GA Lanthanum Carbonate Study Group. Lanthanum carbonate treatment, for up to 6 years, is not associated with adverse effects on the liver in patients with chronic kidney disease Stage 5 receiving hemodialysis. Clin Nephrol 2009;71:286-95.

38. Spasovski GB, Sikole A, Gelev S, Masin-Spasovska J, Freemont T, Webster I, et al. Evolution of bone and plasma concentration of lanthanum in dialysis patients before, during 1 year of treatment with lanthanum carbonate and after 2 years of follow-up. Nephrol Dial Transplant 2006;21:2217-24. http://dx.doi.org/10.1093/ndt/gfl146

39. D'Haese PC, Spasovski GB, Sikole A, Hutchison A, Freemont TJ, Sulkova S, et al. A multicenter study on the effects of lanthanum carbonate (Fosrenol) and calcium carbonate on renal bone disease in dialysis patients. Kidney Int Suppl 2003;85:S73-8. http://dx.doi.org/10.1046/ j.1523-1755.63.s85.18.x

40. Wilhelm M, Gaillard S, Rakov V, Funk F. The iron-based phosphate binder PA21 has potent phosphate binding capacity and minimal iron release across a physiological $\mathrm{pH}$ range in vitro. Clin Nephrol 2014;81:251-8. http://dx.doi.org/ 10.5414/CN108119

41. Floege J, Covic AC, Ketteler M, Mann JF, Rastogi A, Spinowitz B, et al.; Sucroferric Oxyhydroxide Study Group. Long-term effects of the iron-based phosphate binder, sucroferric oxyhydroxide, in dialysis patients. Nephrol Dial Transplant 2015;30:1037-46. http://dx.doi.org/ 10.1093/ndt/gfv006

42. Floege J, Covic AC, Ketteler M, Rastogi A, Chong EM, Gaillard S, et al.; PA21 Study Group. A phase III study of the efficacy and safety of a novel iron-based phosphate binder in dialysis patients. Kidney Int 2014;86:638-47. http://dx.doi.org/10.1038/ki.2014.58

43. Lanz M, Baldischweiler J, Kriwet B, Schill J, Stafford J, Imanidis $G$. Chewability testing in the development of a chewable tablet for hyperphosphatemia. Drug Dev Ind Pharm 2014;40:1623-31. http://dx.doi.org/ 10.3109/03639045.2013.838583

44. Ketteler M, Rix M, Fan S, Pritchard N, Oestergaard O, Chasan-Taber S, et al. Efficacy and tolerability of sevelamer carbonate in hyperphosphatemic patients who have chronic kidney disease and are not on dialysis. Clin J Am Soc Nephrol 2008;3:1125-30. http://dx.doi.org/ $10.2215 /$ C JN.05161107
45. Sheikh MS, Maguire JA, Emmett M, Santa Ana CA, Nicar MJ, Schiller LR, et al. Reduction of dietary phosphorus absorption by phosphorus binders. A theoretical, in vitro, and in vivo study. J Clin Invest 1989;83:66-73. http://dx.doi.org/10.1172/JCl113886

46. Neven E, De Schutter TM, Dams G, Gundlach K, Steppan S, Buchel J, et al. A magnesium based phosphate binder reduces vascular calcification without affecting bone in chronic renal failure rats. PloS One 2014;9:e107067. http://dx.doi.org/10.1371/journal.pone.0107067

47. Pai AB, Jang SM, Wegrzyn N. Iron-based phosphate binders--a new element in management of hyperphosphatemia. Expert Opin Drug Metab Toxicol 2016;12:115-27. http://dx.doi.org/10.1517/17425255.2016.1110573

48. Locatelli F, Spasovski G, Dimkovic N, Wanner C. Long-term evaluation of colestilan in chronic kidney disease stage 5 dialysis patients with hyperphosphataemia. Blood Purif 2016;41:247-53. http://dx.doi.org/10.1159/000441648

49. Ito K, Takeshima A, Shishido K, Wakasa M, Kumata C, Matsuzaka K, et al. Treatment of hyperphosphatemia with bixalomer in Japanese patients on long-term hemodialysis with gastrointestinal symptoms. Ther Apher Dial 2014; 18 Suppl 2:19-23. http://dx.doi.org/10.1111/1744-9987.12229

50. El Borolossy R, El Wakeel LM, El Hakim I, Sabri N. Efficacy and safety of nicotinamide in the management of hyperphosphatemia in pediatric patients on regular hemodialysis. Pediatr Nephrol 2016;31:289-96. http://dx.doi.org/10.1007/s00467-015-3208-1

51. Navaneethan SD, Palmer SC, Vecchio M, Craig JC, Elder GJ, Strippoli GF. Phosphate binders for preventing and treating bone disease in chronic kidney disease patients. Cochrane Database Syst Rev 2011;6:CD006023. http://dx.doi.org/10.1002/14651858.CD006023.pub2

52. Jamal SA, Vandermeer B, Raggi P, Mendelssohn DC, Chatterley T, Dorgan M, et al. Effect of calcium-based versus non-calcium-based phosphate binders on mortality in patients with chronic kidney disease: an updated systematic review and meta-analysis. Lancet 2013;382:1268-77. http://dx.doi.org/10.1016/S0140-6736(13)60897-1

53. Hiremath S, Akbari A. Calcium-based phosphate binders and chronic kidney disease. Lancet 2014;383:216. http://dx.doi.org/10.1016/S0140-6736(14)60070-2

54. St Peter WL, Fan Q, Weinhandl E, Liu J. Economic evaluation of sevelamer versus calcium-based phosphate binders in hemodialysis patients: a secondary analysis using centers for Medicare \& Medicaid services data. Clin J Am Soc Nephrol 2009;4:1954-61. http://dx.doi.org/10.2215/CJN.04100609

55. Manns B, Stevens L, Miskulin D, Owen WF Jr, Winkelmayer WC, Tonelli M. A systematic review of sevelamer in ESRD and an analysis of its potential economic impact in Canada and the United States. Kidney Int 2004;66:1239-47. http://dx.doi.org/10.1111/j.1523-1755.2004.00877.x

56. Palmer SC, Gardner S, Craig JC, Tonelli M, Mavridis D, Johnson DW, et al. Phosphate-binding agents in adults with CKD: a network meta-analysis of randomized trials. Am J Kidney Dis 2016;68:691-702. http://dx.doi.org/10.1053/ j.ajkd.2016.05.015

57. Branley P. Use of phosphate binders in chronic kidney disease. Sydney: KHA-CARI Guidelines; 2005. http://www.cari.org.au/CKD/CKD\%20vitamin\%20D/ The use of phosphate binders in CKD.pdf [cited 2017 Jan 9] 